\title{
Uterine Fistula
}

National Cancer Institute

\section{Source}

National Cancer Institute. Uterine Fistula. NCI Thesaurus. Code C78685.

An abnormal communication between the uterus and another organ. 